\title{
Cymothoid parasite Ceratothoa parallela inflicts great losses on cultured gilthead sea bream Sparus aurata in Greece
}

\author{
E. P. Papapanagiotou ${ }^{1}$, J. P. Trilles ${ }^{2, *}$ \\ ${ }^{1}$ National Center of Marine Research, Aghios Kosmas 16604 Hellinikon, Athens, Greece \\ ${ }^{2}$ Laboratoire d'Ecophysiologie des Invertébrés, Université de Montpellier II, Sciences et Techniques du Languedoc, CP 092, \\ Place E. Bataillon, 34095 Montpellier Cedex 5, France
}

\begin{abstract}
For the first time Ceratothoa parallela (Otto, 1828), a cymothoid isopod, is reported parasitizing cagecultured gilthead sea bream Sparus aurata, in Greece. The specimens observed are larvae (Pullus secundus). They were found in the branchial and buccal cavity of young gilthead sea bream of $2 \mathrm{~g}$ mean body weight, upon introduction in the cages in an intensive cage farm facility. The species was previously known from several species of wild fish, particularly Sparidae (chiefly Boops boops) in the Mediterranean Sea, Adriatic Sea and Atlantic Ocean. However, this is the first documentation of this parasite in cage-cultured gilthead sea bream. Serious lesions were macroscopically visible and typical of a crustacean infection. The cumulative mortality over a 2 mo period was over $50 \%$. The parasitic problem was not successfully dealt with due to high stocking densities and the non removal of the dead fishes, resulting in constant reinfection.
\end{abstract}

KEY WORDS: Cymothoid - Isopod - Parasite $\cdot$ Ceratothoa parallela $\cdot$ Sparus aurata $\cdot$ Greece

Resale or republication not permitted without written consent of the publisher

In recent years, with the expansion of fish aquaculture, occasional parasitic invasions in cage culturing systems have been observed (Raibaut et al. 1980, Euzet et Raibaut 1985, Cabral et Raibaut 1987, Cassier et al. 1998). To date, several species of cymothoid isopods infecting cultured fish have been reported: Ceratothoa gaudichaudii (Milne Edwards, 1840) from salmon Salmo salar farmed in seawater in southern Chile (Roa 1992, Inostroza et al. 1993, Lobos 1994, Sievers et al. 1996); Nerocila orbignyi (Guerin-Meneville, 1829-1832) parasiting cage cultured sea bass Dicentrarchus labrax L., 1758, transferred from wild mullet in Diana Pond in Corsica (Bragoni et al. 1983, 1984); Emetha audouini

*Corresponding author. E-mail: trilles@univ-montp2.fr
(Milne-Edwards, 1840) from cultured sea bass in Greece, transferred from wild populations of Sparidae or Centracanthidae (Papapanagiotou et al. 1999); Ceratothoa oestroides (Risso, 1826), from cultured sea bass and sea bream (Sparus aurata L., 1758) in Croatia (Sarusic 1999).

The occurrence of Ceratothoa parallela (Otto, 1828) on cage-cultured gilthead sea bream Sparus aurata in Greece represents a new interesting case of transferred cymothoids from wild populations to cultured fishes.

Observations and case history. From August to November 2000, a cymothoid infection occurred in a cage farm facility, on the island of Chios in the Aegean, in Greece.

The specimens observed were larvae, pullus secun$d u s$, and 5 to 6 were found in the branchial and buccal cavity of young gilthead sea bream Sparus aurata. The identification of cymothoid isopods from larval specimens only is difficult. However, in accordance with the description of Trilles $(1968,1972)$, the corresponding species was identified as Ceratothoa parallela (Otto, 1828) (Fig. 1). The species has been recorded previously from several species of wild fishes, particularly Sparidae (chiefly Boops boops), in the Mediterranean Sea, the Adriatic Sea and the Atlantic Ocean (Trilles 1994). However, the species is not presently known from farmed fishes and this is the first documentation of this parasite in cage-cultured gilthead sea bream.

The young fishes were introduced to the cage farm directly from a hatchery in 2 batches, at a mean body weight of $2 \mathrm{~g}$ (100000 fishes) and $2.3 \mathrm{~g}$ (40000 fishes). Several days after the arrival of the fish, mortalities started to occur. The course of the mortalities is shown in Fig. 2. The disease lasted for over 2 mo from late 


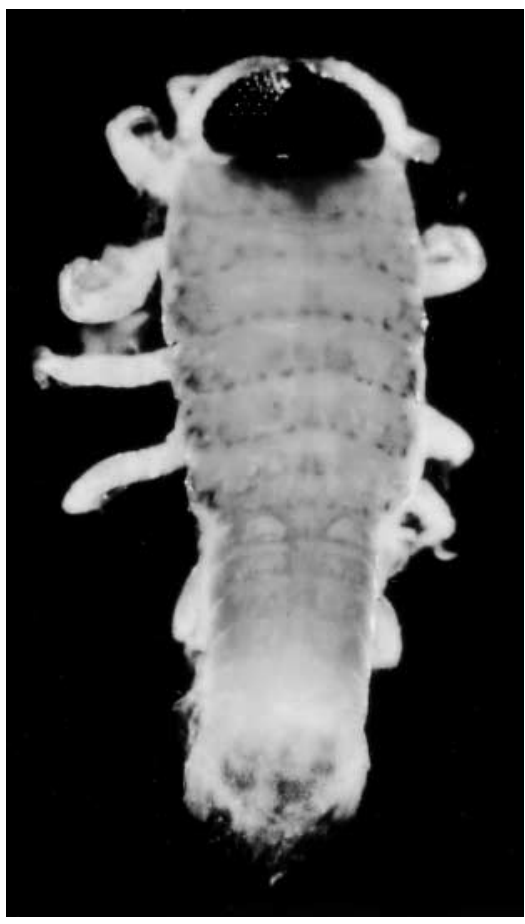

Fig. 1. Ceratothoa parallela (Otto, 1828): specimen (Pullus secundus) collected from cage-cultured gilthead sea bream Sparus aurata, L., in Greece. Dorsal view; length: $2.5 \mathrm{~mm}$. Photograph: G. Charmantier

August 2000 until early November 2000. The cumulative mortality over a 2 mo period was over $50 \%$. The water temperatures during this period ranged from 21 to $23^{\circ} \mathrm{C}$, owing to a prolonged summer that year in Greece. The constant high temperatures during this specific part of the year helped prolong the presence of the isopods in the environment (Trilles 1968). In adjacent cages sea bass were also cultured, but this parasitic infection was not observed in the sea bass.

Formalin baths and use of various antimicrobial chemotherapeutants were ineffective. The general condition of the sea bream was quite poor, and they exhibited anorexia and erratic swimming behavior. Serious lesions were macroscopically visible and typical of a crustacean infection, with extensive and deep skin damage in the head area. The mortalities observed were quite high and the management procedures failed to control the problem. The dead fish were not removed every day, so a constant source of reinfection was always present, keeping the infection at high levels. The very high stocking densities were another factor contributing to the fast transmission of the isopods to the sea bream.

Comments. The parasitic problem reported here is similar to the one observed by Papapanagiotou et al. (1999), who first recorded Emetha audouini, a cymothoid parasite isolated for the first time from cultured sea bass; in that case, the only specimens were larvae. In contrast, larvae and adults of Ceratothoa gaudichaudii, Nerocila orbignyi and Ceratothoa oestroides were recorded by the corresponding authors (see above). In all cases, the effects of parasitism were almost identical, except that in the parasitized Sea bream presented in this communication, losses were considerably higher and the duration of the disease much more prolonged in comparison to sea bass infected with Emetha audouini.

This incidence of Ceratothoa parallela (Otto, 1828) in cultured sea bream shows that great losses can be inflicted if the proper therapeutic measures are not

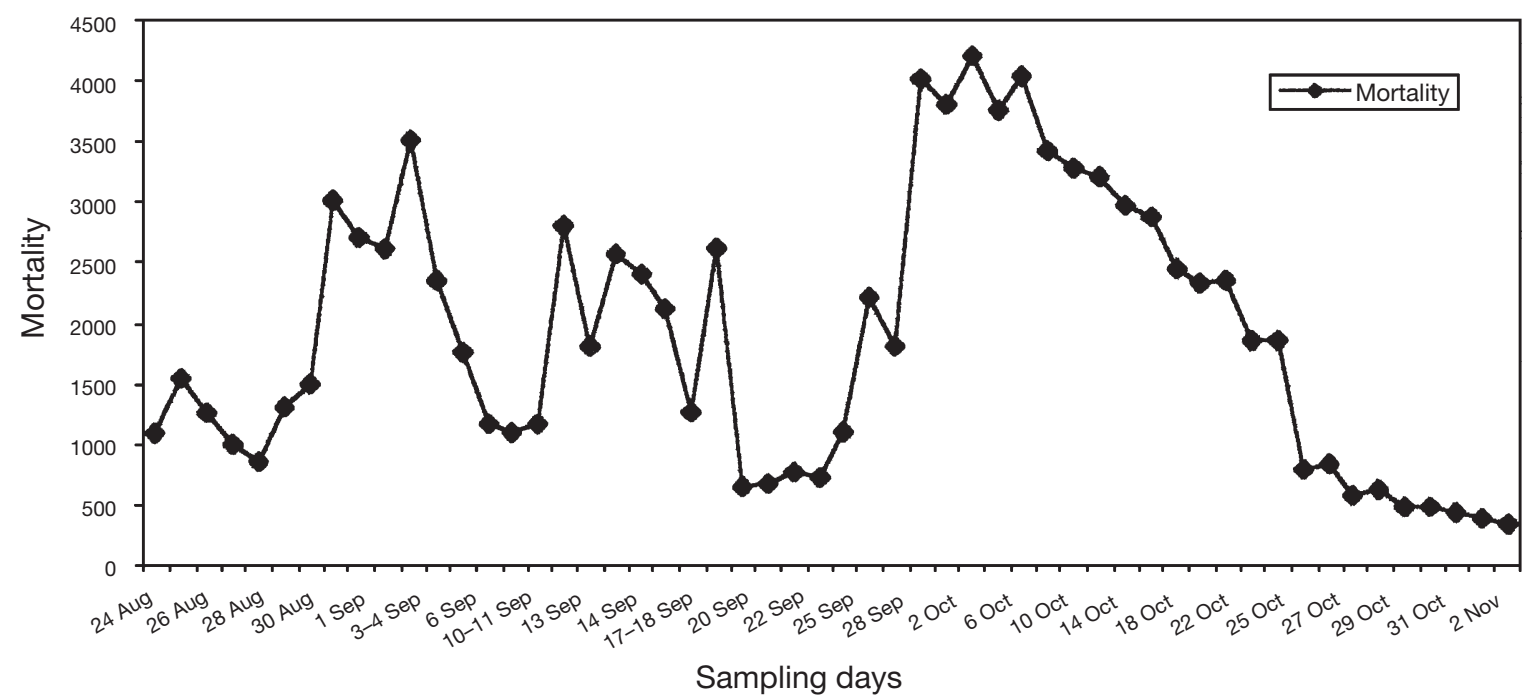

Fig. 2. Profile of the mortalities of cage-cultured gilthead sea bream Sparus aurata L. caused by the cymothoid isopod Ceratothoa parallela (Otto, 1828), over time 
taken to deal with an isopod parasitic incident. Over the past few years the incidents of isopod parasitic diseases have become more frequent and work should be done to improve prophylaxis and therapy against these rather significant fish parasitic pathogens, which are capable of inflicting substantial losses on cultured fish. The toxicity of 8 insecticides (Trichlorfon/neguvon, dichlorvos/Nuvan 1000, fenthion/Baytex, propoxur/Baygon, fenitrothion/folithion, azamethiphos/Alfacron 50 WP, Cyfluthrin/solfac, deltamethrin/K. Othrina EC) in Atlantic salmon Salmo salar and the in vitro effects against the isopode parasite Ceratothoa gaudichaudii were evaluated by Sievers et al. (1995): Trichlorfon, dichlorvos and fenthion were not toxic to fish at the tested concentrations; the first 2 products were $100 \%$ effective against both sizes (1 to 1.5 and 2 to $3 \mathrm{~cm}$ ) of the parasite examined at concentrations of 300 and $3 \mathrm{ppm}$ for $60 \mathrm{~min}$ of exposure, respectively. The experience gained from the use of therapeutic approaches against sea lice (Lepeophtheirus salmonis and Caligus elongatus) from Norway and Scotland should form the basis of a therapy against Mediterranean isopod parasites. In view of the quite different climatological differences between southern Chile and northern Europe (salmon culture) and the Mediterranean (sea bass and sea bream culture), more research should be done on chemotherapeutants known to be effective in the fight against sea lice and the isopods found in the Mediterranean.

The significantly higher water temperatures found in the Mediterranean in contrast to the low water temperatures in Scotland and Norway facilitate the faster uptake of the organophosphorus compounds, which in turn, presents a danger to the fish receiving the therapy (C. Sommerville, Institute of Aquaculture, University of Stirling, UK, pers. comm.). Field experiments in the Mediterranean aquaculture conditions should be strongly encouraged and performed soon in order to combat the emerging new pathogenic species of isopods found in Mediterranean aquaculture.

\section{LITERATURE CITED}

Bragoni G, Romestand B, Trilles JP (1983) Parasitoses à Cymothoadien chez le loup (Dicentrarchus labrax Linnaeus, 1758) en élevage. II. Ecophysiologie parasitaire dans le cas de l'étang de Diana (Haute-Corse). Ann Para-

Editorial responsibility: Wolfgang Körting,

Hannover, Germany sitol Hum Comp 58(6):593-609

Bragoni G, Romestand B, Trilles JP (1984) Parasitoses a Cymothoadien chez le loup Dicentrarchus labrax (Linnaeus, 1758) en élevage. I. Ecologie parasitaire dans le cas de l'étang de Diana (Haute-Corse) (Isopoda, Cymothoidae). Crustaceana 47(1):44-51

Cabral P, Raibaut A (1987) Découverte d'un Copépode Caligide nouveau parasite du tégument du loup Dicentrarchus labrax (L., 1758) (Pisces, Moronidae) en élevage et en milieu naturel. Bull Soc Zool Fr 111(1-2):123-130

Cassier P, Brugerolle G, Combes C, Grain J, Raibaut A (1998) Le parasitisme. Un équilibre dynamique. Masson, Paris

Euzet L, Raibaut A (1985) Les maladies parasitaires en pisciculture marine. Symbioses 17:51-68

Inostroza R, Sievers G, Roa J, Aguirrebeña R (1993) Prevalencia e intensidad de infeccíon estacional por Ceratothoa gaudichaudii en salmones (Salmo salar) cultivados en agua de mar en el sur de Chile. Arch Med Vet (Valdivia) $\mathrm{XXV}(2): 173-179$

Lobos BCI (1994) Accion del isopodo Ceratothoa gaudichaudii sobre el peso corporal de salmones del atlantico (Salmo salar). Tesis de grado de Licenciado en Medicina veterinaria. Universidad austral de Chile, Facultad de ciencias veterinarias, Valdivia, p 1-16

Papapanagiotou EP, Trilles JP, Photis G (1999) First record of Emetha audouini, a cymothod isopod parasite, from cultured sea bass Dicentrarchus labrax in Greece. Dis Aquat Org 38:235-237

Raibaut A, Divanach P, Coste F, Maillard C (1980) Copépodose larvaire en écloserie de poissons marins. La Piscicult Fr 61/62:49-51

Roa RJE (1992) Contribucion al estudio del isopodo Ceratothoa gaudichaudii como parasito de salmones (Salmo salar) cultivados en agua de mar en dos centros de cultivo de la provincia de Llanquihue. Tesis de grado de Licenciado en Medecina veterinaria. Universidad austral de Chile, Facultad de ciencias veterinarias, Valdivia, p 1-31

Sarusic G (1999) Preliminary report of infestation by isopod Ceratothoa oestroides (Risso, 1826), in marine cultured fish. Bull Eur Assoc Fish Pathol 19(3):110-112

Sievers G, Palacios P, Inostroza R, Dölz H (1995) Evaluation of the toxicity of 8 insecticides in Salmo salar and the in vitro effects against the isopode parasite Ceratothoa gaudichaudii. Aquaculture 134:9-16

Sievers G, Lobos C, Inostroza R, Ernst S (1996) The effect of the isopod parasite Ceratothoa gaudichaudii on the body weight of farmed Salmo salar in Southern Chile. Aquaculture 143:1-6

Trilles JP (1968) Recherches sur les Isopodes Cymothoidae des côtes françaises. PhD thesis, University of Montpellier II

Trilles JP (1972) Les Cymothoidae (Isopoda, Flabellifera) des côtes françaises (systématique, faunistique, écologie et répartition géographique). I. Les Ceratothoinae Schioedte et Meinert, 1883. Bull Mus Natl Hist Nat Sect A Zool Biol Ecol Anim 70:1191-1230

Trilles JP (1994) Catalogue mondial des Cymothoidae. Stud Mar 21/22(1-2) (1991):5-288

Submitted: January 2, 2001; Accepted: May 14, 2001 Proofs received from author(s): July 26, 2001 